\title{
Supervisors' perceptions on errors of nursing students in clinical clerkship: a qualitative research
}

Percepções dos supervisores sobre erros dos estudantes de enfermagem em estágio clínico: uma pesquisa qualitativa

Percepciones de los supervisores sobre los errores de los estudiantes de enfermería en prácticas clínicas: una investigación cualitativa

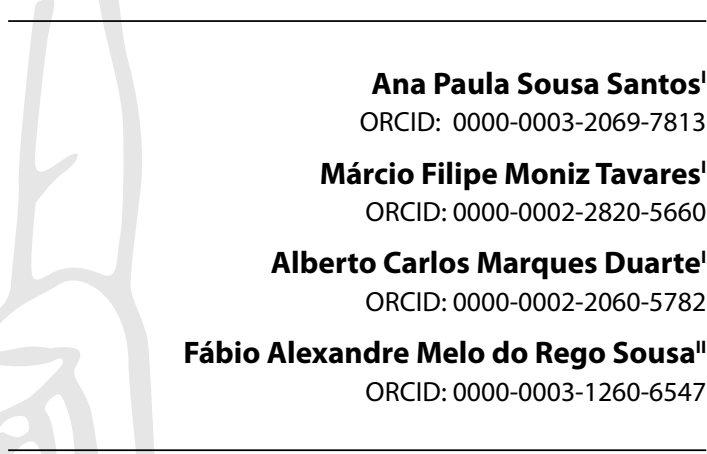

'Universidade dos Açores. Ponta Delgada, Açores, Portugal. "Unidade de Saúde de Ilha de São Miguel. Ponta Delgada, Açores, Portugal.

How to cite this article:

Santos APS, Tavares MFM, Duarte ACM Sousa FAMR. Supervisors' perceptions on errors of nursing students in clinical clerkship: a qualitative research Rev Bras Enferm. 2021;74(2):e20200675 https://doi.org/10.1590/0034-7167-2020-0675

\section{Corresponding author:}

Ana Paula Sousa Santos

E-mail: ana.ps.santos@uac.pt

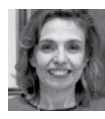

EDITOR IN CHIEF: Antonio José de Almeida Filho ASSOCIATE EDITOR: Fátima Helena Espírito Santo

Submission: $07-23-2020$

Approval: $10-09-2020$

\begin{abstract}
Objectives: to compare pedagogical supervisors' and clinical supervisors' perceptions about the errors made by nursing students in clinical clerkship. Methods: a qualitative exploratorydescriptive study developed with 105 participants. Data collection was performed with a questionnaire with open-ended questions. Content analysis performed according to the conceptual model of student errors in clinical teaching. Results: pedagogical supervisors perceive, in descending order, errors in transversal competencies, in the execution of care and medication. Clinical supervisors perceive, in descending order, the execution of care, medication, and transversal competencies. Final Considerations: there was coincidence and complementarity in clinical supervisors' and pedagogical supervisors' perceptions, although not in the same order, regarding the errors made. This study presents contributions related to the existing knowledge in relation to medication errors, which are not the most perceived, and those of transversal competencies, which take on a prominent position.

Descriptors: Education, Nursing; Students, Nursing; Medical Errors; Qualitative Research Clinical Clerkship.
\end{abstract}

\section{RESUMO}

Objetivos: comparar a percepção de supervisores pedagógicos e de supervisores clínicos sobre os erros cometidos por estudantes de enfermagem em estágio clínico. Métodos: estudo qualitativo exploratório-descritivo, desenvolvido com 105 participantes. Coleta de dados realizada com questionário com perguntas abertas. Análise de conteúdo realizada segundo modelo conceptual de erros de estudantes em ensino clínico. Resultados: os supervisores pedagógicos percebem, em ordem decrescente, os erros nas competências transversais, na execução de cuidados e de medicação. Os supervisores clínicos percebem, por ordem decrescente, a execução de cuidados, de medicação e as competências transversais. Considerações Finais: verificou-se coincidência e complementaridade nas percepções de supervisores clínicos e de supervisores pedagógicos, embora não na mesma ordem, em relação aos erros cometidos. $\mathrm{O}$ estudo apresenta contribuições relativas ao conhecimento existente em relação aos erros de medicação, que não são os mais percebidos, e os de competências transversais, que assumem posição de destaque.

Descritores: Educação em Enfermagem; Estudantes de Enfermagem; Erros Médicos; Pesquisa Qualitativa; Estágio Clínico.

\section{RESUMEN}

Objetivos: comparar la percepción de los supervisores pedagógicos y supervisores clínicos sobre los errores cometidos por los estudiantes de enfermería en práctica clínica. Métodos: estudio cualitativo exploratorio-descriptivo, desarrollado con 105 participantes. Recolección de datos realizada con un cuestionario con preguntas abiertas. Análisis de contenido realizado según el modelo conceptual de errores del alumno en educación clínica. Resultados: los supervisores pedagógicos perciben, en orden decreciente, los errores en las competencias transversales, en la ejecución de los cuidados y la medicación. Los supervisores clínicos perciben, en orden decreciente, la ejecución de cuidados, medicación y habilidades transversales. Consideraciones Finales: hubo coincidencia y complementariedad en las percepciones de los supervisores clínicos y los supervisores pedagógicos, aunque no en el mismo orden, sobre los errores cometidos. El estudio presenta aportes relacionados con el conocimiento existente en relación a los errores de medicación, que no son los más percibidos, y los de habilidades transversales, que asumen un lugar destacado.

Descriptores: Educación en Enfermería; Estudiantes de Enfermería; Errores Médicos; Investigación Cualitativa; Prácticas Clínicas. 


\section{INTRODUCTION}

In general, errors are not comfortable or well accepted. Even so, someone who goes through professional life without making an error is more likely to be the exception than the rule. The possibility of learning and developing safe professional practice resides in the recognition of its existence ${ }^{(1-2)}$.

It is estimated that there are 210,000 to 440,000 deaths per year in the USA due to errors in medical care, including nursing care $^{(3)}$. After entering the present millennium and, according to North American data, health organizations have dedicated efforts to identify the causes of these errors and to institute changes that improve the quality of care and patient safety, but it has been provided less attention to the way students understand these issues. Neither does it exist, for nursing students, learning didactics with errors or near errors, nor instruments that enable training institutions to create an environment that enhances learning with these events ${ }^{(3)}$. However, awareness of this problem is more present in the training of health professionals ${ }^{(4)}$ with regard to the prevention and monitoring of medication errors ${ }^{(5)}$.

Although we did not find data regarding errors in medical care in Portugal, if a trend similar to that observed in the USA is maintained, there would be, in 2010, between 1,330 and 2,900 annual deaths as a result of errors caused by health professionals, which includes nurses ${ }^{(1)}$.

In nursing, where contact and responsibility for well-being and human life are constant, the occurrence of error is poorly considered and often attributed to bad practice. The error that occurs in nursing care refers to failures that result in damage (or have this potential) for the people to whom nurses provide care. In the context of nursing education, it is defined as

a detour, more or less clear, more or less pronounced, between a determined performance of the nursing student, which occurs in a certain context and in relation to a previously defined care performance benchmark in order to perform nursing care with precise intentions ${ }^{(1)}$.

The performance previously outlined refers to the knowledge and skills recommended for student performance, reflected in the program of each curricular unit of clinical teaching, in the rules and procedures and in the clinical clerkship assessment form ${ }^{(1)}$. In this work, we use the term "clinical teaching" when dealing with the course unit and "clinical clerkship" when referring to the teaching/learning process.

Nursing students, due to the teaching/learning process, develop activities with experienced nurses, their clinical supervisors. It has been reported that $40 \%$ of nursing students make errors, most of which are medication errors, of which $12 \%$ have caused damage to customers ${ }^{(3)}$.

In Portugal, students' perceptions about errors made in clinical learning were investigated and it was found that the most common errors were, in descending order of frequency: errors in the execution of care; errors in transversal competencies; errors in identifying needs; errors in care assessment; medication errors; errors in care planning ${ }^{(1)}$. These data contradict those that indicate that medication errors are the most common in these students ${ }^{(3,6-7)}$.
Bearing in mind that clinical clerkship takes place in real contexts, the main players are students, clinical supervisor (service nurses) and pedagogical supervisor (nursing professors). Since there is recent information on students' perception of their errors ${ }^{(1)}$, the research developed focused on the perceptions of pedagogical supervisors (PS) and clinical supervisors (CS) about errors made by nursing students in the context of clinical clerkship. It is these professionals who are responsible for training, learning and developing students' skills, in compliance with ensuring the quality of care and customer safety.

For the present work, we used the concepts of PS and CS adopted by Santos (2019)(1). The first are nursing professors, who are responsible for conceiving and planning the teaching/learning process, formulating objectives, defining supervisory methods and strategies that foster student learning and development, and establishing assessment criteria, methods and strategies. The second are direct nursing care providers, who are responsible for continuous supervision of students, providing them with activities and experiences of real nursing care practice. In their functions, they are partners that complement each other for the achievement of learning objectives and for the development of students' skills ${ }^{(1)}$.

Apart from medication errors, little knowledge has emerged regarding the problem of errors made in the context of training by nursing students. This investigation is based on the need to deepen this problem and contribute to a conscious training that takes into account the safety of the people being cared for. The guiding question was: what are pedagogical supervisors' and clinical supervisors' perceptions about students' errors in clinical clerkship?

\section{OBJECTIVES}

To compare pedagogical supervisors' and clinical supervisors' perceptions about the errors made by nursing students in clinical clerkship.

\section{METHODS}

\section{Ethical aspects}

For access to CS of the hospital where students develop clinical clerkship, authorization was requested from the Board of Directors, which, after consulting the Health Ethics Committee, granted it (S-HDES/2016/492). Authorization was also requested from the Director of the nursing education institution, because when the investigation started, the Ethics Committee of the university to which the researchers belong still did not exist, but, after starting functions, the ongoing investigation was communicated and requested an opinion (UAC/2016/16981).

\section{Theoretical-methodological framework}

The present study fits into the constructivist paradigm, focusing on the perceptions of professionals involved in the training of nursing students in clinical clerkship according to participants' free expression. Perceptions are the focus of nursing research when it is intended to access the way people relate to the world 
and understand it, as all knowledge derives from this form of awareness, making the study of perceptions have outstanding evidence in the philosophy and science. Qualitative research on perceptions allows access, description and comparison of human experiences according to the meaning that each person attributes to them ${ }^{(8)}$. To prepare this article, SRQR was followed.

\section{Type of study}

This is a qualitative, descriptive-exploratory investigation, with a priori categorization and subcategories defined a posteriori. This study followed the methodological proposal of Miles, Huberman and Saldaña ${ }^{(9)}$ and the model of analysis by Santos ${ }^{(1)}$.

\section{Methodological procedures}

Data collection took place between February and October 2016. Participants answered a questionnaire that included the following open-ended question: give examples of serious errors that have occurred by students who have undergone clinical supervision (in their report, avoid all and any information that may violate ethical and deontological principles, such as institution where it happened, name or data that enables the identification of customers, name of health professionals, among others).

\section{Study setting}

This study was developed in two different contexts: i) in a department where nursing is taught at a Portuguese university, where PS were accessed; ii) at the central hospital, the main partner of the university in nursing training, where CS develop their professional activity, under a protocol between the institutions.

\section{Data source}

Participants were all nursing professors (PS) and all nurses in services (CS) who met the following inclusion criteria: all PS in function when collecting data; all CS who have collaborated with the university since 2008 who had at least previous supervisory experience.

In total, 17 PS participated, having answered 16. Regarding CS, the total of questionnaires distributed was 162,89 being returned.

\section{Data collection and organization}

Data collection with PS took place before it was done with CS. For the former, the questions were sent by email, and the responses were returned by the same means. In the email, we explain the objectives, purpose, method of data processing and analysis, benefits, risks, as well as aspects related to data privacy and confidentiality. Therefore, consent was tacit, manifested by sending responses. To protect privacy, only the main investigator (MI) sent and received e-mails, having subsequently copied the content of the responses and purged all information that could identify the participant.

Concerning CS, after obtaining consent, the entire data collection protocol was prepared, which included the information leaflet for participants, the Informed Consent Form and the open-ended questionnaire. The documents were placed in a closed envelope, one for each participant, who was in charge of the head nurse or someone designated by them. After two weeks, participants returned their responses and the completed Informed Consent Form, also in a closed envelope, through the same person. Thus, there was no previous contact with participants.

\section{Data analysis}

The questionnaires received were enumerated and transcribed so that participants were not identified. Analysis matrices were also prepared, which enabled data analysis and included the number of the questionnaire, answer transcription, units of analysis, categories and their respective subcategories.

Data analysis was manual, following Santos' model ${ }^{(1)}$.This model was developed by the author in the context of PhD, encompassing the following categories: "Errors in identifying needs"; "Errors in care planning"; "Errors in the execution of care"; "Errors in care assessment"; "Errors in transversal competencies"; "Medication errors". The subcategory "Respect for ethical and deontological principles" was included in this study in the "transversal competencies" category, due to the recurrence with which it appeared. Using this model made it possible to compare the results between PS and CS in a coherent way, with a unifying line of investigation. The analysis process, according to Miles, Huberman and Saldaña ${ }^{(10)}$, encompasses the stages of data reduction, data presentation, data collection and verification.

Coding was validated by all investigators in a triangular review process in which investigator $A$ reviewed the work done by investigator $B$, who reviewed that of investigator $C$, who in turn reviewed that of investigator $D$, who reviewed that of researcher A. While this process was developing, the team met for discussion, measurement and consensus building. The agreement rate was $87 \%$. From an ethical point of view, we are based on the Belmont Report, issued by the National Commission for the Protection of Human Subjects of Biomedical and Behavior Research in 1979(11).

For the purposes of understanding, hierarchizing and comparing participants, we chose to account for the categories and subcategories.

\section{RESULTS}

PS's teaching time was between 10 and 34 years. The CS were nurses for at least 3 years and their experience of supervising students was between 2 and 30 years.

Three PS responded that they never had occurrences that considered serious errors. Similar response was reported by $41 \mathrm{CS}$.

Figures 1 and 2 show the categories of errors made by students according to the perception of PS and CS who participated in this study.

In PS, in the first place, errors in transversal competencies arise, whereas in CS, it is in relation to the execution of care. Secondly, errors in execution of care appear in PS, and this place in CS is medication errors. These errors occupy the third place in PS, whereas in CS, this position is occupied by the perception of errors in transversal competencies. 


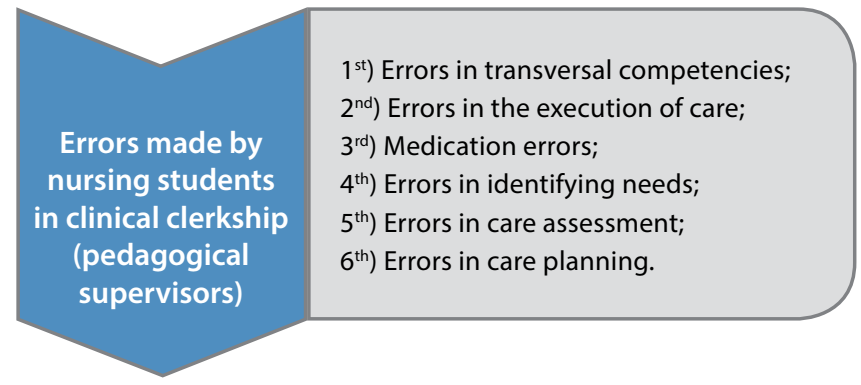

Figure 1 - Errors made by students in clinical clerkship according to pedagogical supervisors' perceptions

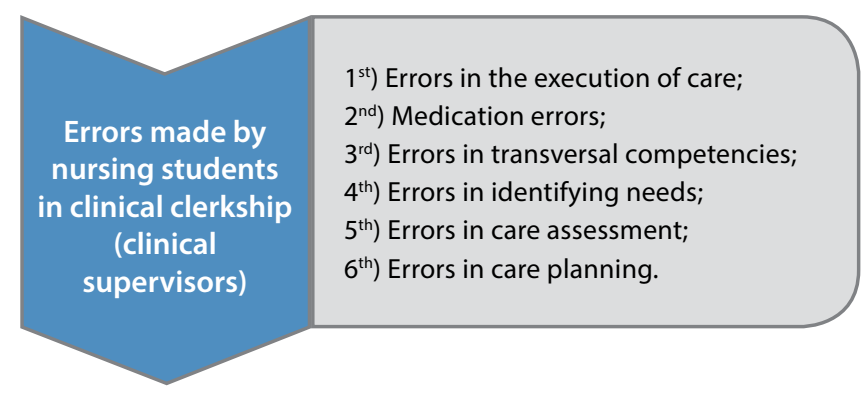

Figure 2 - Errors made by students in clinical clerkship according to clinical supervisors' perceptions

The fourth, fifth and sixth place of errors perceived by PS and CS is identical, referring, respectively, to errors in identifying needs, errors in care assessment and errors in care planning.

Following the steps of the nursing process and comparing PS' and $\mathrm{CS}^{\prime}$ perceptions (Chart 1), we find that, in relation to errors in identifying needs, the highlight for both is in "Identifying customers' needs through observation", whereas in the "Therapeutic relationship with customers that allows identifying their needs" no errors were noticed.

Chart 1 - Errors made by nursing students in clinical clerkship. Comparison between pedagogical supervisors' and clinical supervisors' perceptions, Ponta Delgada, Portugal, 2016

\begin{tabular}{|l|l|c|c|}
\hline \multirow{2}{*}{ Category } & Subcategory/ies & \multicolumn{2}{|c|}{ Supervisors } \\
\cline { 2 - 4 } & $\begin{array}{l}\text { Customers' needs } \\
\text { identification through the } \\
\text { clinical process. }\end{array}$ & 1 & 4 \\
\cline { 2 - 4 } $\begin{array}{l}\text { Errors in } \\
\text { identifying } \\
\text { needs }\end{array}$ & $\begin{array}{l}\text { Identification of customers' } \\
\text { needs through themselves } \\
\text { and/or their family. }\end{array}$ & 1 & 2 \\
\cline { 2 - 4 } & $\begin{array}{l}\text { Therapeutic relationship } \\
\text { with customers that allows } \\
\text { identifying their needs. }\end{array}$ & 0 & 0 \\
\cline { 2 - 4 } & $\begin{array}{l}\text { Customers' needs } \\
\text { identification through } \\
\text { observation. }\end{array}$ & 4 & 5 \\
\hline \multirow{2}{*}{$\begin{array}{l}\text { Errors in care } \\
\text { planning }\end{array}$} & $\begin{array}{l}\text { Definition of Nursing } \\
\text { Diagnostics according to } \\
\text { customers' needs in their } \\
\text { different dimensions. } \\
\text { Customer follow-up. } \\
\text { Priority setting. }\end{array}$ & 0 & 0 \\
\hline
\end{tabular}

To be continued

\begin{tabular}{|c|c|c|c|}
\hline \multirow{2}{*}{ Category } & \multirow{2}{*}{ Subcategory/ies } & \multicolumn{2}{|c|}{ Supervisors } \\
\hline & & Pedagogical & Clinical \\
\hline $\begin{array}{l}\text { Errors in care } \\
\text { planning }\end{array}$ & $\begin{array}{l}\text { Definition of expected results, } \\
\text { stated in feasible and realistic } \\
\text { terms. }\end{array}$ & 0 & 0 \\
\hline \multirow{7}{*}{$\begin{array}{l}\text { Errors in the } \\
\text { execution of } \\
\text { care }\end{array}$} & $\begin{array}{l}\text { Justification of the procedures } \\
\text { inherent to nursing care } \\
\text { implementation. }\end{array}$ & 4 & 7 \\
\hline & $\begin{array}{l}\text { Implementation of procedures } \\
\text { in accordance with the } \\
\text { respective standard. }\end{array}$ & 8 & 41 \\
\hline & $\begin{array}{l}\text { Adaptation of care to } \\
\text { customers' needs. }\end{array}$ & 8 & 7 \\
\hline & $\begin{array}{l}\text { Maintenance of customer } \\
\text { privacy during care } \\
\text { implementation. }\end{array}$ & 0 & 1 \\
\hline & $\begin{array}{l}\text { Using communication } \\
\text { techniques with customers } \\
\text { during care implementation. }\end{array}$ & 3 & 2 \\
\hline & $\begin{array}{l}\text { Provision of care according } \\
\text { to the characteristics of each } \\
\text { customer. }\end{array}$ & 6 & 2 \\
\hline & $\begin{array}{l}\text { Execution of planned care in a } \\
\text { timely manner. }\end{array}$ & 0 & 1 \\
\hline \multirow{3}{*}{$\begin{array}{l}\text { Errors in care } \\
\text { assessment }\end{array}$} & $\begin{array}{l}\text { Assessment of the progression } \\
\text { of customers according to the } \\
\text { expected results. }\end{array}$ & 1 & 1 \\
\hline & $\begin{array}{l}\text { Preparation of records } \\
\text { with relevant and useful } \\
\text { information for the continuity } \\
\text { of care. }\end{array}$ & 1 & 1 \\
\hline & $\begin{array}{l}\text { Modifying the care plan } \\
\text { according to the assessment } \\
\text { carried out. }\end{array}$ & 3 & 1 \\
\hline \multirow{6}{*}{$\begin{array}{l}\text { Errors in } \\
\text { transversal } \\
\text { competencies }\end{array}$} & $\begin{array}{l}\text { Demonstration of theoretical } \\
\text { knowledge in identifying } \\
\text { customer needs. }\end{array}$ & 3 & 9 \\
\hline & $\begin{array}{l}\text { Performance independent of } \\
\text { supervisor guidance. }\end{array}$ & 1 & 7 \\
\hline & $\begin{array}{l}\text { Setting strategies to overcome } \\
\text { difficulties. }\end{array}$ & 2 & 1 \\
\hline & Assumption of errors made. & 2 & 10 \\
\hline & $\begin{array}{l}\text { Seeking help from other } \\
\text { professionals (including nurses } \\
\text { and/or professors) when } \\
\text { matters are beyond their } \\
\text { competence. }\end{array}$ & 0 & 0 \\
\hline & $\begin{array}{l}\text { Respect for ethical-deontological } \\
\text { principles. }\end{array}$ & 17 & 9 \\
\hline $\begin{array}{l}\text { Medication } \\
\text { errors }\end{array}$ & & 7 & 38 \\
\hline
\end{tabular}

The category "Errors in care planning" records only those related to "Priority setting", in the two types of participants.

Errors in the "Execution of care" present a greater number of perceptions concerning the "Implementation of procedures according to the respective standard" by PS and CS, even though 
PS present in ex aequo the subcategory "Adaptation of care to customers' needs", referred to in second place by CS.

Errors in care assessment provided show more perceptions in "Modifying the care plan according to the assessment carried out" by PS. CS perceive errors in the three items in this category identically.

"Respect for ethical-deontological principles" is the target of more perceptions in the errors of transversal competencies by PS. In CS, it occupies the second place, in an equal number of enumeration units, "Demonstration of theoretical knowledge in identifying customer needs". For CS, the most perceived item in this category is "Assumption of errors made".

Medication errors were more perceived by CS, the second most frequently mentioned, after, "Implementation of procedures according to the respective standard". They are in third place of perception by PS.

\section{DISCUSSION}

We found that PS perceive, firstly, errors in transversal competencies, then the ones in the execution of care and then medication, whereas in CS they were the execution of care, medication and transversal competencies, respectively. These results appear to be expected given the role of healthcare providers in CS, whereas PS highlight those that are detectable in any context, essentially denoting the complementarity of roles, functions and responsibilities shared by the main players in the teaching/learning process of nursing students in clinical clerkship ${ }^{(12)}$.

Contrary to what is indicated by the scientific literature in relation to the fact that the most common errors reported are those related to medication ${ }^{(3,6,13-14)}$, they were not the most reported in the present study.

In identifying needs, more observation errors are noticed. Observation is an essential instrument in the provision of nursing care, being systematic and requiring knowledge and experience. Its development, from beginner to expert, implies systematic and guided guidance in the context of effective practice with planning that includes the cognitive, affective and psychomotor dimensions ${ }^{(1,15)}$.

PS and CS point out, in care planning, errors in priority setting. Care planning involves decision making and critical thinking. It is an intellectual and ethical activity, assuming the establishment of objectives and priorities, as well as the selection of intervention strategies. Errors of this type compromise all subsequent performance ${ }^{(1,13,16)}$, since planning is indispensable for providing safe nursing care $^{(17)}$.

Implementing a procedure following a standard requires knowledge transfer. Simultaneously, dexterity and skill develop progressively throughout the course in earlier stages, with the need to use lists and very detailed details in which the students' concentration is focused on the task to later evolve into a practice more spontaneous ${ }^{(1,15)}$. Nursing has a component of psychomotor domain based on the very evident and valued cognitive domain ${ }^{(18)}$, which is in line with the results obtained in PS and CS. These data denote the attention paid to these capacities and how much it requires the attention of everyone involved as it is the one in which the most errors were noticed.
Transversal competencies register the types of errors most noticed by PS, and the second, of CS, related to the respect for ethical-deontological principles. These data reinforce the importance that nurses, nursing professors and nursing students, involved in the training process, understand the human being as a person as

a social being and intentional agent of behaviors based on the values, beliefs and desires of the individual nature, which makes each person a unique being, with their own dignity and the right to self-determination ${ }^{(19)}$

who is cared for and the primary reason for the existence of nursing as a profession, and must meet a set of ethical principles and deontological determinants. From an ethical perspective, the principle of the Dignity of the Human Person is bastion, underpinning the founder of all other principles and values that constitute the axiological pillar of human relationship ${ }^{(19)}$.In addition to the ethical dimension, it is also important to consider the deontological as a set of rules that indicates how the behavior should be in a given professional body. This notion of mandatory praxis through an imposed or imposed duty should be the subject of constant reflection on the part of all those involved in the nursing training process.

For CS, however, the most perceived errors in this category were in admitting the errors made. It seems plausible to us to think that, for students to admit an error and seek help from a supervisor, it is necessary to establish a relationship of trust and mutual respect. It is when they admit an error and analyzes it with a supervisor that students can repair, minimize the consequences and learn from what happened, developing themselves personally and professionally ${ }^{(1)}$. It is essential to admit and accept responsibility in order to enhance situations in which an error has occurred as a learning opportunity and as a way to ensure care and customer safety ${ }^{(20-22)}$.

\section{Study limitations}

We recognize that the interview could have complemented, and deepened aspects related to PS' and CS' perceptions.

\section{Knowledge progression}

This study finds that the errors of nursing students perceived by the main players in their education, PS and CS, are beyond those generally mentioned in the bibliography, i.e., medication. Those related to transversal competencies and knowing how to act in a situation are the most perceived. The complementary appreciation of each partner in the training process indicates the indispensable contribution of each of these professionals to the students' learning and development. Respect for ethical-deontological principles is perceived as something in which students make errors, which suggests that PS and CS are attentive to this important dimension of transversal competencies in nursing.

\section{Contributions to nursing}

We suggest extending the study to other clinical clerkship contexts of nursing students, in order to also integrate CS' perceptions originating from other professional contexts such as primary health care. 
Based on the results, we present the following suggestions: 1) The partnership between PS and CS is indispensable for the development of nursing students' knowledge and skills in clinical clerkship. This partnership promotes the transfer and appropriation of knowledge from the classroom to the real of care delivery contexts; 2) The entire medication administration process must be supervised by a nursing professional, preferably CS; 3 ) In the face of an error, students should be encouraged by CS and PS to reflect on it, causes, associated factors, what to do after the event and strategies to avoid future occurrences. It is essential that they are encouraged to take on what has happened, which implies an environment and a relationship of trust with supervisors and in which they do not feel threatened; 4) PS and CS must develop sensitivity in themselves and encourage it in students in relation to respect for ethical-deontological principles, encouraging reflection at this level; 5) All stakeholders must be aware that students begin to develop their activities based on fragmented reasoning, through lists and checklists, and, only later, depending on experience and reflection, they have cognitive, mental and emotional availability to act in a more fluid and comprehensive way and not just focused on the task. As reflection is central to this process, oral and written forms of critical reflection must be promoted throughout training; 6) Psychomotor practice should be provided to each student, accompanied by theoretical and critical reflection, which implies using simulated practice laboratories with professors that facilitate the learning process. Simultaneously, during clinical clerkship, it is essential that psychomotor training is encouraged and valued with feedback and reflection as close as possible to the act, in order to self-regulate cognitive processes, developing security and allowing progression to more advanced stages of skills development.

\section{FINAL CONSIDERATIONS}

When analyzing and comparing PS' and CS' perceptions in relation to types of errors made by nursing students in clinical clerkship, we find that they have a complementary understanding in the most evident perceptions. On the part of PS, errors in transversal competencies and those in the execution of care are highlighted, with medication in third place. In the references of CS, in the first place, those of execution of care, with medication and transversal competencies in second and third place, respectively. Errors in identifying needs, care assessment and care planning appear in the same order in both supervisors.

This complementarity indicated in the roles of PS and CS are enhancers in facilitating praxis - knowledge transfer from theory to practice and practice to consolidate theory, in a constructivist process of acquiring knowledge and developing skills.

\section{REFERENCES}

1. Santos APS. Nursing students' errors in clinical learning. Qualitative outcomes in Mixed Methods Research. Rev Bras Enferm. 2019;72(1):1706. https://doi.org/10.1590/0034-7167-2018-0592

2. Disch J, Barnsteiner J, Connor S, Brogren F. Exploring how nursing schools handle student errors and near misses. Am J Nurs. 2017;117(10):24-31. https://doi.org/10.1097/01.NAJ.0000525849.35536.74

3. Carver N, Gupta V, Hipskind JE. Medical Error. In: StatPearls [Internet]. Treasure Island (FL):StatPearls Publishing; 2020[cited 2020 May 23]. Available from: https://www.ncbi.nlm.nih.gov/books/NBK430763/

4. Mendonça V, Gallagher T, Hendryx N. Medical error: concept, characterization and management. Saude Soc. 2019;28(4):255-66. https://doi. org/10.1590/S0104-12902019180105

5. Cancino KD, Arias M, Caballero E, Escudero E. Development of a safe drug administration assessment instrument for nursing students. Rev Latino-Am Enferm. 2020;28:(e3246). https://doi.org/10.1590/1518-8345.2989.3246

6. Öztürk H, Kahriman I, Bahcecik AN, Sökmen S, Calbayram N, Altundag S, et al. The malpractices of student nurses in clinical practice in Turkey and their causes. J Pak Med Assoc [Internet]. 2017 [cited 2020 Apr 26];67(8):1198-205. Available from: http://www.ncbi.nlm.nih.gov/ pubmed/28839304.

7. Tabassum N, Allana S, Saeed T, Dias JM. Reported medication errors committed by undergraduate (Four Year BScN) Students at AKU-SoNaM, Karachi, Pakistan. Int J Nurs Educ. 2015;7(3):94-8. https://doi.org/10.5958/0974-9357.2015.00142.7

8. Moser A, Korstjens I. Series: Practical guidance to qualitative research. Part 3: Sampling, data collection and analysis. Eur J Gen Pract. 2018;24(1):9-18. https://doi.org/10.1080/13814788.2017.1375091.

9. Miles MB, Huberman AM. Qualitative Data Analysis: An Expanded Sourcebook. Thousand Oaks: Sage Publications; 1994.408 p.

10. Burns N, Grove SK. The practice of nursing research: appraisal, synthesis, and generation of evidence. 8th ed. Philadelphia: W.B. Saunders; 2016. 736p.

11. United States Commission for the Protection of Human Subjects of Biomedical and Behavioral Research. USA: Andesite Press; $2015,38 \mathrm{p}$.

12. Glynn DM, McVey C, Wendt J, Russell B. Dedicated educational nursing unit: clinical instructors role perceptions and learning needs. J Prof Nurs. 2017;33(2):108-12. https://doi.org/10.1016/j.profnurs.2016.08.005

13. Orbæk J, Gaard M, Fabricius P, Lefevre RS, Møller T. Patient safety and technology-driven medication: a qualitative study on how graduate nursing students navigate through complex medication administration. Nurse Educ Pract. 2015;15(3):203-11. https://doi.org/10.1016/j. nepr.2014.11.015 
14. Musafiri J, Daniels F. Nursing students' perceptions of clinical learning opportunities and competence in administration of oral medication in the Western Cape. Curationis. 2020;43(1):1-9. https://doi.org/10.4102/curationis.v43i1.2044

15. Benner P. Curricular and Pedagogical Implications for the Carnegie Study, Educating Nurses: A Call for Radical Transformation. Asian Nurs Res (Korean Soc Nurs Sci). 2015;9(1):1-6. https://doi.org/10.1016/j.anr.2015.02.001

16. Drach-Zahavy A, Somech A, Admi H, Peterfreund I, Peker H, Priente O. (How) do we learn from errors? A prospective study of the link between the ward's learning practices and medication administration errors. Int J Nurs Stud. 2014;51(3):448-57. https://doi.org/10.1016/j. ijnurstu.2013.06.010

17. Braga LM, Salgado PO, Souza CC, Prado-Junior PP, Prado MRMC, Melo MN, Parreira PMSD.The Betty Neuman model in the care of patients with a peripheral venous catheter. Rev Enf Ref. 2018;4(19):159-168. https://doi.org/10.12707/RIV18029

18. Eyikara E, Baykara ZG. The Importance of simulation in nursing education. WJET[Internet]. 2017 [cited 2020 Apr 26];9(1):2-7. Available from: https://files.eric.ed.gov/fulltext/EJ1141174.pdf

19. Ordem dos Enfermeiros. Conselho de Enfermagem. Padrões de qualidade dos cuidados de enfermagem. Enquadramento conceptual. Padrões descritivos [Internet]. 2001 [cited 2020 Apr 26]. 24 p. Available from: https://www.ordemenfermeiros.pt/media/8903/divulgarpadroes-de-qualidade-dos-cuidados.pdf

20. Jahromil MK, Manesh EP, Hejazi F, Moosavifar ZS, Poorgholami F. Professional values of the nursing students' perspective in Jahrom University of medical sciences, 2017. BJMS. 2020;19(3):427-32. https://doi.org/10.3329/bjms.v19i3.45859

21. Latimer S, Hewitt J, Stanbrough R, McAndrew R. Reducing medication errors: teaching strategies that increase nursing students' awareness of medication errors and their prevention. Nurse Educ Today. 2017;52:7-9. https://doi.org/10.1016/j.nedt.2017.02.004

22. Aydin Y, Turan Z, Dikmen Y. Identification the Level of Tendency in Malpractıce among Midwife and Nurse Interns. Int J Caring Sci[Internet]. 2016[cited 2020 Apr 26];9(2):463-70. Available from: http://www.internationaljournalofcaringsciences.org/docs/10_Aydin_originial_9_2.pdf 